\title{
PENGUATAN PEMAHAMAN BIDANG SOSIAL DAN KEAGAMAAN BAGI MASYARAKAT MELALUI KEGIATAN KKN-PAR DI KELURAHAN OI FO'O KOTA BIMA
}

\author{
Umar', Syarifuddin', Ihwan ${ }^{3}$, Kuriawansyah ${ }^{4}$ \\ Institut Agama Islam (IAI) Muhammadiyah Bima, Indonesia ${ }^{1,2,3,4}$
}

Corresponding Author: Umar, 这laodeumarpgmi@gmail

\section{ABSTRAK}

Dalam mengatasi masalah yang ada di Kelurahan Oi Fo'o Kota Bima diperlukan berbagai metode pengabdian salah satunya dengan pendekatan metode PAR (Participatory Action Research). Pelaksanaan kegiatan pengabdian berbasis diharapkan masalahmasalah yang sering menjadi problem terutama pada bidang sosial dan bidang keagamaan. Salah satu bentuk upaya dalam mengatasi masalah di kelurahan ini yang bernilai sosial dengan mengadakan sebuah kegiatan positif-edukatif bagi seluruh

ARTICLE INFO

Article history:

Received

8 Januari 2022

Revised

13 Januari 2022

Accepted

17 Januari 2022 masyarakat di Kelurahan Oi Fo'o, seperti; mengadakan seminar hukum dengan tema "Bahaya Narkoba Bagi Masa Depan" sebagai salah satu bentuk partisipasi terhadap masyarakat guna meminimalisir masalah kenakalan remaja yang terjadi ditengahtengah masyarakat, sehingga memberikan dampak yang baik bagi kehidupan sosial masyarakat Kelurahan Oi Fo'o. Hal yang sama juga dilakukan berkenaan dengan masalah keagamaan dengan cara merangsang minat belajar anak-anak yang sebelumnya sangat minim menjadi lebih tinggi disebabkan dengan adanya kegiatan pembinaan tahsin dan lomba keagamaan yaitu hafalan ayat pendek dan adzan, selebihnya masyarakat sangat merasa terbantu dengan diadakannya kegiatan edukatif ini dengan pendekata-pendekatan tertentu yang efisien bagi masyarakat di Kelurahan Oi Fo'o Kota Bima.

Kata Kunci: KKN PAR, Bidang Sosial, Keagamaan, Masyarakat

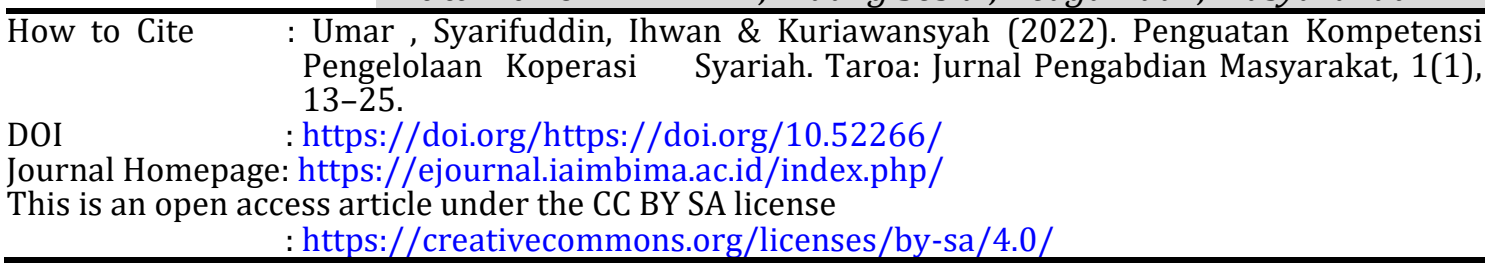

\section{PENDAHULUAN}

$\mathrm{K}$ elurahan Oi Fo'o merupakan pemekaran dari Kelurahan Kumbe dan Kelurahan Rabadompu berdasarkan Peraturan Daerah Kota Bima Nomor 19 Tahun 2006 tentang Pembentukan Kelurahan Oi Fo'o pada tanggal 11 September 2006. Jika dibandingkan dengan kelurahan-kelurahan lain yang berada di wilayah administrasi Kota Bima, maka kelurahan Oi Fo'o termasuk kelurahan yang cukup tertinggal. Jika kita berkunjung dikeluarahan Oi Fo'o secara kasat saja kita sudah bisa menilai bahwa kondisi masyarakat disana masih jauh tertinggal dari masyarakat Kota Bima pada umunya. Melalui kegiatan survey, diperoleh gambaran kondisi masyarakat disana. Mayoritas 
hunian masyarakat disana masih banyak yang berupa rumah kayu, selain itu banyak masyarakat yang tidak memiliki sarana MCK, meskipun dibeberapa titik telah ada, hasil bantuan dari pemerintah. Dua kondisi tersebut jika kita merujuk pada indicator masyarakat pra sejahtera Badan Pusat Statistik (BPS), maka kondisi masyarakat disana sudah dapat kita golsongkan sebagai masyarakat pra sejahtera. Namun hasil ini tidak didukung oleh data dari kelurahan yang menunjukan kondisi ekonomi masyarakat disana. (Arsip, 2015)

Beberapa faktor yang berhasil di identifikasi sebagai penyebab kondisi pra sejahtera masyarakat Oi Fo'o adalah: 1) Kondisi geografis. Letak geografis kelurahan Oi Fo'o sangat mempengaruhi corak ekonomi masyarakat disana. Letaknya yang berada diatas daerah pegunungan kapur yang kurang subuh dan tidak memiliki akses terhadap air bersih yang memadai, menjadi penyumbang utama masalah perekonomian masyarakat. Pertanian tidak bisa menjadi andalan ekonomi bagi masyarakat disana meskipun terdapat banyak lahan garapan yang bisa dioptimalisasi dengan menanam komiditas pertanian yang memiliki nilai jual dikarenakan lahan pertanian disana mengandalkan air hujan. Sehingga kegiatan pertanian hanya bisa dilakukan jika sudah memasuki musim penghujan, sementara pada saat musim kemarau lahan-lahan dibiarkan kosong tanpa ada kegiatan pertanian. Hanya disebagian kecil dari lahan pertanian yang dialiri air yang berasal dari sumber mata air pegunungan saja yang bisa ditanami sayuran yang tetap peroperasi sepanjang tahun. 2) Sosial. Permasalahan sosial dimasyarakat disana adalah kenakalan remaja (Tim KKN PAR, 2021)

Berdasarkan keterangan masyarakat disana, kenakalan remaja telah berada pada kondisi yang cukup memprihatinkan karena remaja disana telah terkontaminasi dengan narkotika. Untuk itu perlu pedidikan non formal sejak dini seperti keberadaan PIAUD, TPQ, dan tempat les Pendidikan untuk anak-anak dan remaja, sehingga waktu luang yang mereka miliki bisa dialokasikan untuk belajar tambahan. Seperti belajar IQRA, mengaji, belajar Kembali mata pelajaran yang telah diajarkan disekolah. 3). Rendahnya peran aparatur kelurahan. Berdasarkan penjelasan sebelumya, Kelurahan Oi Fo'o merupakan kelurahan baru hasil pemekaran dari Kelurahan Kumbe dan Rabadompu, sehingga untuk saat ini, administrasi kelurahan belum lengkap, seperti informasi kondisi geografis, peta wilayah kelurahan, data kependudukan masyarakat kelurahan, yang akan mempengaruhi kebijakan aparatur kelurahan. Ditambah lagi, kurangnya keterlibatan langsung lurah yang merupakan penduduk yang berasal dari luar wilayah Kota Bima sehingga kehadirannya ditengah masyarakat sangat rendah. Selain itu keberadaan tokoh agama jumlahnya sangat sedikit, padahal peranan tokoh agama sangat penting untuk membangun kehidupan sosial masyarakat disana. (Tim KKN PAR, 2021)

Sisi positif dari kehidupan masyarkat di Kelurahan Oi Fo'o adalah masyarakat disana masih mempertahankan budaya gotong-royong dengan baik untuk kepentingan bersama. dan ditengah keterbatasan yang ada masyarakat disana cukup mandiri dalam mencari nafkah, seperti menjadi penenun kain khas Bima (Tembe), menjadi peternak sapi, kambing dan ayam potong, tukang bangunan, dan petani sayuran. Pada sisi yang lain, masyarakat Kelurahan Oi Fo'o Kota Bima juga memiliki antusias dalam pendidikan keagamaan sehingga menjadi modal yang sangat penting untuk meciptakan generasi yang baik. Masyarakat Oi Fo'o terutama para orang tua sangat ingin anak-anaknya tumbuh menjadi pribadi yang baik, mereka khawatir dengan kondisi remaja dikelurahan mereka 
sekarang yang terjerumus dalam candu narkotika (Amiruddin, personal communication, June 20, 2021). Namun terdapat kendala dalam pengembangan Pendidikan keagamaan kepada anak ini yaitu, jumlah TPQ tidak sesuai dengan kebutuhan anak-anak disana serta jaraknya yang jauh dari tempat tinggal Sebagian masyarkaat. Contohnya di lingkungan Rade Ndeu yang berada di ujung Kelurahan Oi Fo'o. Menurut masyarakat disana, kendala dalam mendidik anak-anak mereka dari sisi agama sejak dini terletak pada akses tempat menimba ilmu agama yang jumlahnya kurang memadai karena tidak banyak orang yang bisa mengajar ngaji. Sehingga apabila ingin anak-anak mereka belajar ngaji maka mereka harus pergi ke tempat yang agak jauh dari tempat tinggal mereka. (Muh. Adnan, 2021)

Namun rasa antusias yang besar saja tidak cukup untuk merubah keadaan, jika tidak dibarengi dengan aksi nyata. Peran para orangtua disana sangat rendah dalam mengarahkan anak mereka untuk menjadi pribadi yang baik, karena para orangtua sangat sibuk mencari nafkah atau hal yang lainnya. Mereka menganggap bahwasanya yang terpenting adalah kebutuhan materi bagi sang anak, apabila hal ini telah terpenuhi maka sudah cukup. Ini adalah merupakan suatu bentuk kekeliruan dari sang orang tua. Memang kebutuhan materi itu penting, namun yang lebih penting dari hal tersebut adalah kebutuhan rohani untuk sang anak. Sehingga sang anak kurang mendapatkan kasih sayang dan juga bimbingan dari orang tuanya. Orang tua cukup apatis terhadap pergaulan anak hal ini tergambar dari aktivitas anak-anak hingga remaja yang lebih banyak meluangkan waktunya untuk duduk nongkrong dan main games dari pada datang menimba ilmu ditempat Pendidikan keagamaan. Di tambah lagi dengan kondisi aparatur kelurahan yang kurang berpartisipasi kepada masyarakat, yang berkaitan dengan administrasi yang sangat lamban di peroleh oleh masyarakat seperti anggaran kegiatan perlombaan 17 Agustus, anggaran tata kelola TPQ dan kurang terlibat dalam kegiatan yang diadakan oleh masyarakat sehingga ini menjadi penyebab di mana masyarakat mengalami degradasi dalam pengembangan lingkungan dan wilayah baik dari segi pendidikan, sosial dan keagamaan di kelurahan Oi Fo'o Kota Bima.

\section{TINJAUAN TEORITIS}

\section{Konsep Dasar KKN-PAR (Participatory Action Research)}

Secara aplikatif pelaksanaan model KKN (Kuliah Kerja Nyata) yang dilakukan sekarang ini adalah KKN berbasis PAR (Participatory Action Research). Pada dasarnya PAR merupakan penelitian yang melibatkan semua pihak yang relevan dalam meneliti secara aktif bersama-sama tindakan saat ini terhadap suatu masalah dalam rangka untuk mengubah dan memperbaikinya (Mansour, 2002). Pelaksanaan kegiatan KKN-PAR didasari oleh pencapaina kebutuhan dalam melakukan perubahan terhadap berbagai persolan dalam kehidupan sosial masyarakat (Tim LPM, 2008). PAR tidak bisa terpisah dari partisipasi bahkan hal ini menjadi keharusan dan mutlak diperlukan dalam setaiap kegiatan dan pelaksanaan KKN-PAR di tengah-tengah kehidupan masyarakat (Suwartiningsih, 2015). Sedangkan berdasarkan metodelogi kerja PAR, ketiga variabel yaitu partisipasi, riset, dan aksi (Agus Afandi, 2015). Adapun penjabaran istilah ketiga domain variabel PAR sebaigaimana di atas anatra lain:

1) Research atau penelitian, tahap ini merupakan menelusuri tentang permasalahan yang dihadapi masyarakat, permasalahan tersebut dipahami secara kritis dan detail sehingga masalah tersebut bisa diketahui dengan jelas penyebab dan akibatnya. 
2) Action atau aksi, setelah mengetahui masalah-masalah tersebut secara mendalam dan mendetail, barulah masuk dalam langkah yang kedua yaitu pencarian alternatif untuk memecahkan masalah tersebut yang kemudian diterjemahkan dalam beberapa item dalam program kerja yang akan dilaksanakan.

3) Participatory, kedua item di atas dilaksanakan secata partisipasi artinya dengan melibatkan seluruh komponen masyarakat dalam melakukan identifikasi masalah serta teknik untuk mencari solusi secara bersama-sama dan melakukan secara bersamasama pula bukan saja sebagai penonton atau gaya bos yang hanya bisa memerintah tetapi tidak bisa bekerja (Moh. Nazir, 2005)

Partisipasi dalam PAR adalah proses aktif yang inisiatifnya dilakukan oleh masyarakat sendiri dan dibimbing oleh cara berfikir mereka sendiri dengan menggunakan sarana, proses dan mekanisme tertentu yang dapat menegakkan proses pengawasan secara efektif. participation action research melibatkan pelaksanaan penelitian untuk mendefinisikan sebuah masalah maupun menerapkan informasi ke dalam aksi sebagai solusi atas masalah. Selain itu, participation action research teramsuk serangkaian penelitian oleh, dengan, dan untuk orang "bukan" penelitian terhadap orang". Pelaksanaan kegiatan PAR mengharuskan adanya tingkat partisipatif setiap elemen/kelompok masyakat yang menjadi subjek kegiatan PAR. Dalam arti bahwa pengembangan kegiatan PAR menghendaki satu kondisi yang melibatkan orang agar memainkan peran kunci di dalamnya dan memiliki informasi yang relevan tentang sistem sosial tengah berada di bawah pengkajian, bahwa mereka berpartisipasi dalam rancangan dan implementasi rencana aksi itu didasarkan pada hasil penelitian (Tim LPPM, 2020).

Memaknai dari makna PAR diatas, tentu didapatkan simpulannya bahwa mahasiswa (peneliti) bersama-sama dengan masyarakat melakukan identifikasi masalah perencanaan dan aksi untuk menyelesaikan persoalan-persoalan yang mereka hadapi. Di samping itu, nuansa research nya serta kritik yang konstruktif terhadap kondisi masyarakat tersebut menjadi tugas independen mahasiswa sebagai bentuk laporan pertanggungjawaban atas keterlibatan atas proses perubahan yang dilakukan bersama mayarakat. Secara umum prinsip-prinsip PAR, ialah 1) belajar dari realitas atau pengalaman; 2) tidak menggurui, dan 3) proses belajar dijalankan dengan dialogis. Walaupun pilihan KKN-PAR sangat tampak jelas dan memiliki peran yang signifikan. Masyarakat tidak lagi menjadi objek tetapi masyarakat bersama mahasiswa adalah merupakan subjek dari proses tersebut tetapi peran mereka sangat berbeda. Masyarakat berperan sebagai seorang yang telah menentukan masalahnya, meneruskan, merencanakan dan melaksanakan kegiatankegiatan yang telah terencana sementara mahasiswa bertujuan sebagai motivator, dinamisator, fasilitator, katalisator dan pendamping masyarakat dalam merumuskan dan memecahkan masalah yang mereka hadapi (Tim LPPM, 2020).

\section{CIRI-CIRI DASAR KKN-PAR (Participatory Action Research)}

Terdapat 3 hal pokok yang membedakan PAR dengan penelitian biasa, yaitu keterlibatan partisipan (hampir semuanya terlibat), penelitian didasarkan pada analisis sosial (problem sebuah komunitas) dan orientasi pada komunitas. Oleh karena itu, ada beberapa ciri-ciri dasar PAR yang perlu di ingat, antara lain:

1) Dibangun dalam semangat gerakan pembebasan; 
2) Sebuah proses di mana kelompok sosial kelas bawah mengontrol ilmu pengetahuan, kekuasaan, dan kekuatan politik melalui pendidikan orang dewasa, penelitian kritis, dan tindakan sosial-politik.

3) Proses membangun kesadaran diri melalui penyelidikan dan refleksi diri dengan Bergama menggunakan beragam metode diantranya; (a) produksi pengetahuan oleh komunitas mengenai agenda kehidupan mereka sendiri, (b) partisipasi dalam pengumpulan dan analisa data, dan (c) kontrol mereka terhadap penggunaan hasil riset. (d) orientasi lebih pada proses perubahan sistem sosial (Suwartiningsih, 2015).

\section{SISTEM KERJA KKN- PAR (Participatory Action Research)}

Landasan utama dalam sistem kerja PAR, terutama adalah gagasan-gagasan yang datang dari masyarakat dilapangan pengabdian (KKN). Oleh karena itu, PAR harus melakukan sistem kerja, antara lain:

1) Perhatikan dengan sungguh-sungguh gagasan yang datang dari rakyat yang masih terpenggal dan belum sistematis;

2) Pelajari gagasan tersebut secara bersama- sama dengan mereka sehingga menjadi gagasan yang sistematis;

3) menyatulah dengan rakyat;

4) Kaji kembali gagasan yang datang dari mereka, sehingga mereka sadar dan memahami bahwa gagasan itu milik mereka sendiri;

5) Terjemahkan gagasan tersebut dalam bentuk aksi;

6) Uji kebenaran gagasan melalui aksi;

7) dan seterusnya secara berulang-ulang sehingga gagasan tersebut menjadi lebih benar, lebih penting dan lebih bernilai sepanjang masa (Tim LPPM, 2020).

Untuk lebih mudah cara kerja di atas dapat dirancang dengan suatu daur gerakan sosial sebagai berikut:

1) Pemetaan Awal (Preleminary mapping)

Pemetaan awal sebagai alat untuk memahami komunitas sebagi subjek kegiatan PAR akan memudahkan seorang peneliti dalam memahami realitas problem dan relasi sosial yang terjadi. Dengan demikian akan memudahkan masuk ke dalam komunitas baik melalui key people (kunci masyarakat) maupun komunitas akar rumput yang sudah terbangun, seperti kelompok keagamaan (yasinan, tahlilan, masjid, musholla dll), kelompok kebudayaan (kelompok seniman, dan komunitas kebudayaan lokal), maupun kelompok ekonomi (petani, pedagang, pengrajin dll).

2) Membangun Hubungan Kemanusiaan

Peneliti melakukan inkulturasi dan membangun kepercayaan (trust building) dengan masyarakat, sehingga terjalin hubungan yang setara dan saling mendukung. Peneliti dan masyarakat bisa menyatu menjadi sebuah simbiosis mutualisme untuk melakukan riset, belajar memahami masalahnya, dan memecahkan persoalannya secara bersama-sama (partisipatif).

3) Penentuan Agenda Riset untuk Perubahan Sosial

Bersama komunitas, peneliti mengagendakan program riset melalui teknik Partisipatory Rural Aprasial (PRA) untuk memahami persoalan masyarakat yang selanjutnya menjadi alat perubahan sosial. Sambil merintis membangun kelompokkelompok komunitas, sesuai dengan potensi dan keragaman yang ada. 


\section{4) Pemetaan Masalah Kemanusiaan}

Bersama komunitas melakukan pemetaan wilayah, maupun persoalan yang dialami masyarakat. Selanjutnya Komunitas merumuskan masalah mendasar hajat hidup kemanusiaan yang dialaminya. Seperti persoalan pangan, papan, kesehatan, pendidikan, energi, lingkungan hidup, dan persoalan utama kemanusiaan lainnya.

5) Menyusun Strategi Gerakan

Komunitas menyusun strategi gerakan untuk memecahkan problem kemanusiaan yang telah dirumuskan. Menentukan langkah sistematik, menentukan pihak yang terlibat (stake holder), dan merumuskan kemungkinan keberhasilan dan kegagalan program yang direncanakannya serta mencari jalan keluar apabila terdapat kendala yang menghalangi kebehasilan program.

6) Pengorganisasian Masyarakat

Komunitas didampingi peneliti membangun pranata- pranata sosial. Baik dalam bentuk kelompok-kelompok kerja, maupun lembaga-lembaga masyarakat yang secara nyata bergerak memecahkan problem sosialnya secara simultan. Demikian pula membentuk jaringan-jaringan antar kelompok kerja dengan lembaga-lembaga lain yang terkait dengan program aksi yang direncanakan.

7) Melancarkan aksi perubahan

Aksi memecahkan problem dilakukan secara simultan dan partisipatif. Program pemecahan persoalan kemanusiaan bukan sekedar untuk menyelesaikan persoalan itu sendiri, tetapi merupakan proses pembelajaran masyarakat, sehingga terbangun pranata baru dalam komunitas dan sekaligus memunculkan community organizer (pengorganisir dari masyarakat sendiri) dan akhirnya akan muncul local leader (pemimpin lokal) yang mejadi pelaku dan pemimpin perubahan.

8) Membangun pusat-pusat belajar masyarakat

Pusat-pusat belajar dibangun atas dasar kebutuhan kelompok-kelompok komunitas yang sudah bergerak melakukan aksi perubahan. Pusat belajar merupakan media komunikasi, riset, diskusi, dan segala aspek untuk merencanakan, mengorganisir dan memecahkan problem sosial. Hal ini karena terbangunnya pusat-pusat belajar merupakan salah satu bukti munculnya pranata baru sebagai awal perubahan dalam komunitas masyarakat. Bersama masyarakat pusat-pusat belajar diwujudkan dalam komunitaskomunitas kelompok sesuai dengan ragam potensi dan kebutuhan masyarakat. Seperti kelompok belajar perempuan petani, kelompok perempuan pengrajin, kelompok tani, kelompok pemuda, dan sebagainya. Kelompok tidak harus dalam skala besar, tetapi yang penting adalah kelompok memiliki anggota tetap dan kegiatan belajar berjalan dengan rutin dan terealisir dalam kegiatan yang terprogram, terencana, dan terevaluasi. Dengan demikian kelompok belajar merupakan motor penggerak masyarakat untuk melakukan aksi perubahan.

9) Refleksi (Teoritisasi Perubahan Sosial)

Peneliti bersama komunitas dan didampingi dosen DPL merumuskan teoritisasi perubahan sosial. Berdasarkan atas dasar riset, proses pembelajaran masyarakat, dan program- program aksi yang sudah terlaksana, peneliti dan komunitas merefleksiakan semua proses dan hasil yang diperolehnya (dari awal sampai akhir). Refleksi teoritas dirumuskan secara bersama, sehingga menjadi sebuah teori akademik yang dapat dipresentasikan pada khalayak publik sebagai pertanggungjawaban akademik. 
10) Meluaskan Skala Gerakan Dan Dukungan

Keberhasilan program PAR tidak hanya diukur dari hasil kegiatan selama proses tetapi juga diukur dari tingkat keberlanjutan program yang sudah berjalan dan munculnya pengorganisir-pengorganisir serta pemimpin lokal yang melanjutkan program untuk melanjutkan aksi perubahan. Oleh sebab itu, bersama komunitas peneliti memperluas skala gerakan dan kegiatan. Mereka membangun kelompok komunitas baru di wilayah baru yang dimotori oleh kelompok dan pengorganisir yang sudah ada. Bahkan diharapkan komunitas-komunitas baru itu dibangun oleh masyarakat secara mandiri tanpa harus difasilitasi oleh pendiri. Dengan demikian masyarakat akan belajar sendiri, melakukan riset, dan memecahkan problem sosialnya secara mandiri(Tim LPPM, 2020).

\section{METODE PENGABDIAN}

Kegiatan pengabdian masyarakat ini dalam bentuk penguatan pemahaman bidang sosial dan keagamaan bagi masyarakat melalui kegiatan KKN-PAR Di Kelurahan Oi Fo'o Kota Bima yang dilaksanaakan selama kegiatan KKN Mahasiswa IAI Muhammadiyah Bima Tahun 2021. Kegiatan pengabdian masyarakat ini diawali dengan proses indentifikasi berbagai masalah sosial dan kegamaan dinataranya; 1) masalah kenakalan remaja yang orientasinya lebih kepada konsumsi narkoba, minuman-minuman keras, berpacaran dibawah umur, pergaulan bebas. 2) masalah Pernikahan dini menggambarkan adanya sejumlah anak dibawah umur yang sudah menikah, sesuai dari hasil observasi bahwa jumlah masyarakat dalam pernikahan usia dini ini kurang lebih terdapat 20 orang warga di Kelurahan Oi Fo'o Kota Bima. Kegiatan pengabdian masyarakat ini menggunakan pendekatan PAR yang dilaksanakan secara kaloboratif dengan melibatkan berbagai elemen masyarakat di Kelurahan Oi Fo'o muai para pejabat pemerintahan kelurahan, para tokoh agama, praktisi pendidikan, komunitas majelis ta'alim, remaja majsid, unsur pemuda dan umumnya masyarakat Kelurahan Oi Fo'o. Adapun bentuk pelaksanaan kegiatan pengabdian masyarakat ini dilakukan secara kaloboratif menenakan pada serangkaian kegiatan-kegiatan seminar dan pembinaan bebasis komunitas pada aspek keagamaan bagi masyarakat Di Kelurahan Oi Fo'o Kota Bima.

\section{HASIL DAN PEMBAHASAN}

\section{Penguatan Pemahaman Bidang Sosial Tentang Bahaya Narkoba Dan Penikahan Dini Bagi Masyarakat Di Kelurhan Oi Fo'o Kota Bima}

Peredaran barnga haram Narkoba secara nasional sangat menghkwatirkan bagi keberlangungan perkebngan generasi Indonesia. Penggunaan Narkoba berbagi jenis mulai sabu-sabu, putaw, pil ekstasi, ganja, heroin, yang dikemas dengan berbagi model seolah tidak pernah mati dan telah menggurita diberbagi kalangan masyarakat Indonesia. Silih berbaganti para bandar, pengeda dan pemakai dijebloskan dalam penjara. Bahkan diantara mereka ada yang di hukum mati, di hukum seumur hidup, penjara 15 tahun, sampai yang paling ringan dilakukan rehabilitasi bagi para pemakai Narkoba. Penggunaan narkoba di kalangan masyarkat beberapa dekade terakhir ini hampir menjangkiti semua klaster sosial masyarakat mulai dari kalangan pejabat pemerintah, ASN, politisi, para selebiritas, teramsuk kalangan masyarakat biasa dengan keampuan eknomomi pas pasan di tanah air. Mirisnya lagi, penggunaan narkoab tidak hanay dilakukan oleh orang dewasa, melainkan juga telah menyisir pada kalangan remaja. Dalam hal ini, menurut Kepala 
Badan Narkotika Nasional (BNN) Komisiaris Jenderal Polisi Heru Winarko menyebut, bahwa penyalahgunaan narkotika menunjukan adanya peningkatan sebesar $24 \%$ hingga $28 \%$ kalangan remaja Indonesisa yang menggunakan narkotika. Bahkan bila merujuk data 5 tahun terakhir angka penyalahgunaan Narkoba di kalangan pelajar di tahun 2018 (dari 13 ibukota provinsi di Indonesia) mencapai angka 2,29 juta orang. Salah satu kelompok masyarakat yang rawan terpapar penyalahgunaan narkoba adalah mereka yang berada pada rentang usia 15-35 tahun atau generasi milenial. Sehingga peredaran narkoba sekarang ini harus diwapai secara bersama-sama demi keberlangsungan generasi muda Indonesia (Puslitdatin BNN, 2019).

Sejalan dengan kondisi nasional di atas, generasi di daerah termasuk di Kota Bima juga dihadapkan dengan problem terkait masifnya peningkatan penggunaan narkoba di kalangan masyarakat Kota Bima. Berangkat hal tersebut, maka penting bagi setaip pemangu kebijakan, para parktisi sosial, tokoh mayarakat, tokoh pendidikan teramsuk perguruan tinggi agar di daerah daerah agar mengupaya kegiatan-kegatan akdemik dan tri dharma perguruan tinggi baik dalam bentuk sosialisasi maupun seminar tentang bahaya laten penggunaan narkoba pada kalangan remaja. Oleh sebab itu, melalui pelaksanaan kegiatan KKN-PAR Mahasiswa IAI Muhammadiyah Bima maka diselenggara seminar yang bertema "Pencegahan Penggunaan Narkoba Bagi Generasi Muda Di Kelurahan Oi Fo'o Kota Bima". Kegiatan semina ini dilaksanakan pada hari Senin, 09 Agustus 2021 di Kantor Lurah Oi Fo'o. Dalam kegiatan seminar ini, kami mendatangkan narasumber dari Badan Narkotika Nasional (BNN) dan mengundang para pemuda dan masyarakat di Kelurahan Oi Fo'o Kota Bima. Seminar ini bertujuan agar Masyarakat Kelurahan Oi Fo'o Kota Bima khususnya kepada Pemuda dapat mengetahui bahaya narkoba dan dampak konsumsi narkoba berbahaya bagi perkembangan fisik mereka serta masa depan mereka.

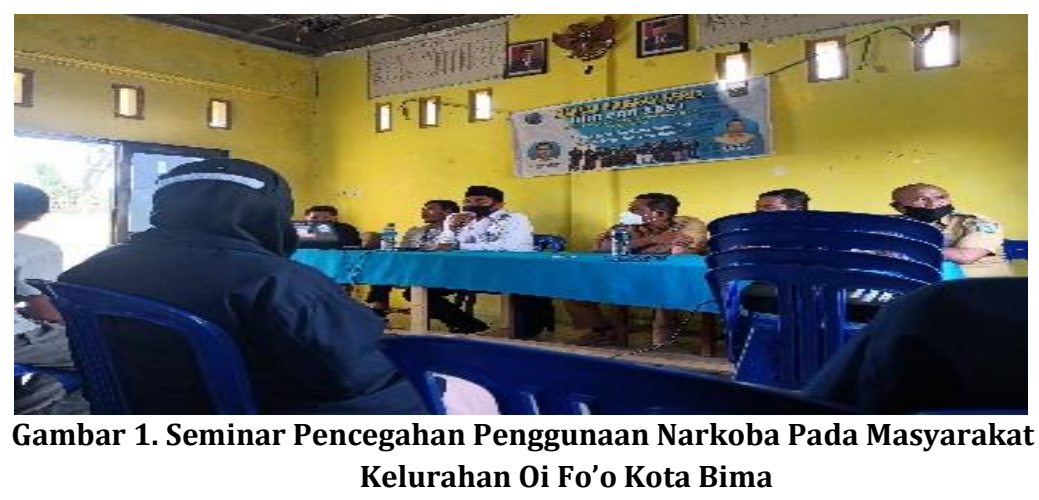

Pelaksanaan seminar yang bertema pencegahan penggunaan narkoba bagi generasi muda yang di isi langsung oleh anggota BNN di kantor lurah pukul 08:30 Wita yang dihadiri oleh Bapak Lurah, para pemuda, warga masyarakat, tokoh agama dan pendidikan, seraja jajaran seluruh staf kelurahan Kelurahan Oi Fo'o Kota Bima diharapkan dapat memberikan dampak positif terhadap upaya bersama dalam pencegahan penggunaan narkoba dilangan remaja dan pemuda khusus dilingkungan di Kelurahan Oi Fo'o Kota Bima. Sebab, dalam mencegah penggunaan narkoba dikalangan masyarakat mestinya menjadi tanggung jawab bersama, seluruh elemen masyarakat dan jajaran pemerintahan. Salah satunya melalui kegiatan-kegiatan seminar anti narkoba maupun dalam bentuk sosialisasi bahaya narkoba bagi para pemuda dan remaja. Menurut Sri Purwatiningsih 
dalam jurnalnya menjelaskan bahwa upaya penanggulangan maslah narkoba sangat memerlukan sinergisitas dan kordinasi antara lembaga pemerintah dan masyarakat agar bisa berajan efektif. Lebih lanjut, ia juga menambahkan terdapat tiga kategori untuk menanggulangi maslah narkoba diantranya; 1) meningkatkan penerapan hukum pada pengguna narkoba. Pendekata ini tidak mendorong pengguna narkoba, tetapi mempunyai efek samping yang merusak, termasuk tumbuhnya organsisasi krimininal subkultut narkoba. 2) program treatment, bagi pengguna narkoba untuk membantu mengentikan penggunaan narkoba, dan program treatment yang paling berhasil ialah dengan menggunakan beberbaik bentuk dukunga kelompok. 3) meningkatkan toleransi sosial dari penggna narkoba, termasuk dalam kategori ini adalah legasasi, diskriminasi, dan pengelolaan klink rehabilitasi. Program tratemn ini banyak di terampkan di Amerika yang secara signifikan cukup efektuf menangani pecandu heroin (Purwatiningsih, 2016).

Selain persoalan masifnya penggunaan narkoba pada kalangan remaja, masalah yang menjadi konsen kegiatan KKN-PAR IAI Muhammadiyah Bima di Kelurahan Oi Fo'o Kota Bima, juga berhubungan dengan upaya membangun pemahaman para orang tua dan remaja terkait bahaya pernikahan usia dini. Hal ini didasarkan pada data observasi di lapangan terungkap informasi terkait maraknya pernikahan usia dini pada dikalangan remaja di Kelurahan Oi Fo'o Kota Bima. Berdasarkan data obseravsi dan interview dengan beberapa tokoh masyrakat, ditemukan lebih kurang 20 pasangan suami-sitri dengan rentan usia sangat muda muda yang menikah di usia dini. Terjadinya proses perinikahan dini pada usia remaja di kelompok sosial masyakat disebabkan oleh berbagai hal di antaranya; karena faktor sosial budaya, faktor ekonomi, faktor pergaulan para remaja, maupun faktor pandangan kegamaan dari sebagai masyarakat terutama dibagian pedesaan yang masih konservatif memandang pernikahan sebagai upaya moral dan keharusan sosial untuk dilaksanakan guna mencegah perbuatan perzinaan darai para remaja. Padahal bila merujuk pada jabaran pasal 7 ayat (1) Undang-Undang Perkwinan No. 1/1974 sebagai hukum positif Indonesia, telah menetapa batas umr perkawinan bagi laki-laki adalah 19 tahun dan bagi perempuan 16 tahun. Batas usia tersebut, bkan merupakan batas usia seseorang telah cukup dewasa untuk bertindak, akan tetapi batas usia tersebut hanya merupakan batas usia minimal/batas bawah seseorang boleh melakukan pernikahan. Dan di dalam pasal 6 ayat (2) juga dijelaskan bahwa seseorang dikatakan dewasa kalau sudah mencapai umur 21 tahun, sehingga dalam melakukan pernikahan tidak perlu mendapat izin dari kedua orang tuanya (Faridatul Jannah, 2012).

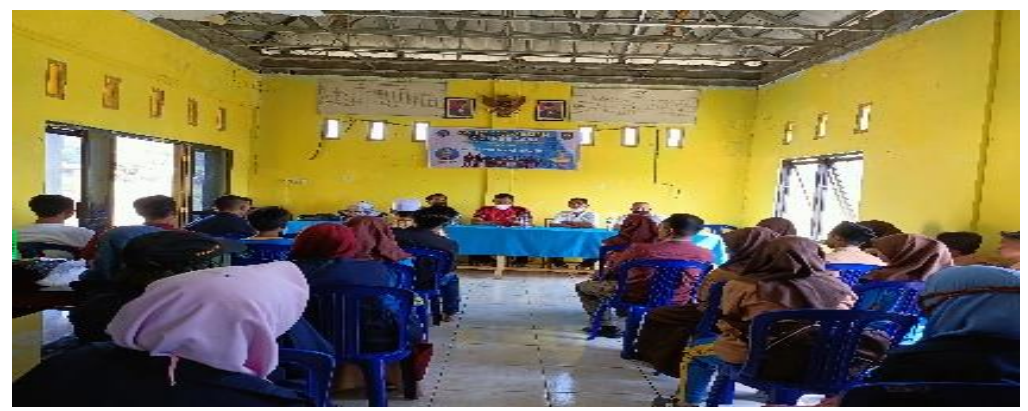

Gambar 3. Seminar Dampak sosial Pernikahan Usia Dini Di Kelurahan Oi Fo'o Kota Bima

Sehubungan dengan kondisi inilah, melalui program kegiatan KKN-PAR IAI Muhammadiyah Bima Bima di Kelurahan Oi Fo'o Kota Bima diselenggarakan seminar 
peningkatan kesadaran terkait dengan dampak sosial pernikahan usia dini bagi para remaja. Seminar ini dilaksanakan pada hari Jumat, 20 agustus 2021 pukul 08:30 di aula Kelurahan Oi Fo'o Kota Bima dihadiri oleh seluruh RT,RW, anak-anak serta remaja dari masyarakat Kelurahan Oi Fo'o Kota Bima, acara disi oleh dinas lembaga perlindungan anak (LPA) sebagai narasumber,seminar ini bertujuan agar mendidik anak-anak serta remaja jauh dari pergaulan bebas dan pernikahan dini. Pelaksanaan seminar yang bertema Dampak Sosial Pernikahan Usia Dini yang di isi langsung oleh anggota LPA, di kantor Kelurahan Oi Fo'o Kota Bima yang pukul 08:30 Wita yang dihadiri oleh 15 siswa SMPN 53 kelurahan oi fo'o, warga kelurahan, dan langsung didampingi oleh Bapak Lurah Oi Fo'o serta staf jajarannya.

Pelaksanaan seminar tentang dampak sosial pernikahan usia dini di kalangan remaja di Kelurahan Oi Fo'o Kota Bima diharapkan menumbuhkan kesadaran para orang dana masyarakat secara umum, bahwa sesungguhnya pernikahan usia dini bagi para remaja akan berdampak buruk terhadap perkembangan anak. Dampak yang yang paling nampak akibat afdanya pernikahan pada usia dini, yakni adanya potensi ketidak harmonisan dalam berumah tangga. Sebab, seseorang yang remaja yang dihadapkan dengan struktur keluarga dan memikul tanggung jawab besar sebagai suami maun istri belum sepenuhnya memiliki kematangan emosional dalam membangun mahligia rumah tangga. Pada kahirnnya prosesi pernikahan usia dini secara faktual ada kencendurungan memiliki banyak dampak negatif. Pernikahan usia dini juga mempengaruhi secara negatif masa depan perempuan, membatasi gerak sang perempuan, membuat mereka tak punya kesempatan melakukan berbagai hal pada usia tersebut(Alfa, 2019).

Hasil penelitian yang dikemukan oleh Alfa dalam jurnalnnya "Pernikahan Dini Dan Perceraian Di Indonesia menjelaskan lebih dari Dari 33.5\% perempuan yang menikah pada usia dini, hanya sekitar $5.6 \%$ yang masih melanjutkan pendidikannya. Namun, apabila harus memasuki dunia kerja, mereka juga tidak siap karena minimnya pengetahuan dan pengalaman. Selain itu, pernikahan dini menempatkan perempuan pada kerentanan untuk mengalami Kekerasan Dalam Rumah Tangga. Sekitar 44\% perempuan yang menikah dini mengalami kekerasan dalam rumah tangga (KDRT) dengan frekuensi yang cukup tinggi. Sedangkan, 56\% perempuan sisanya mengalami KDRT dalam frekuensi rendah. Banyaknya jumlah tersebut dipicu karena tingginya pernikahan di bawah umur. Hal ini bisa terjadi, karena biasanya pelaku pernikahan dini memang belum memiliki kesiapan ekonomi maupun mental untuk berumah tangga. Sedikit badai sangat rawan menggoyahkan rumah tangga pelaku pernikahan dini (Alfa, 2019). Dengan demikian, menurut hemat penulis sangat penting bagi para orang tua, tokoh masayarakat dan para pemanku kebijakan di Kelurahan Oi Fo'o Kota Bima untuk memanimilisir potensi koservatifnya sebagai pandangan masyarakat yang melaksanakan menikahkan di usia dini melalui Gerakan sosialisa mapun seminar tenga pernikah ideal yang baik menuru undangundang positif Indonesia. Meskipun disadari bahwa upaya tersebut bukan suatau pendekatan yang mudah untuk dilakukan, tetapi bila didasarai dengan kesadar kolektif akan adanya pernikahan usia dini adanya keinginan bersaama demi masa depan genarasi masyarakat di Kelurahan Oi Fo'o Kota Bima. 


\section{Penguatan Pemahaman Bidang Keagamaaan Melalui Kegiatan Pembinaan Tahsin Dan Lomba Azan Bagi Masyarakat Di Kelurhan Oi Fo'o Kota Bima}

Dalam perkembangan zaman di era teknologi inforamasi dan komunikasi yang begitu pesat ini ada kecenderungan generasi muda menghabiskan waktu untuk bermain game dan memalingkan target capaian masa depan mereka. sehingga kegiatan belajar dengan sungguh-sungguh tidak lagi menjadi skala prioritas dalam kehidupan seharai-hari mereka. pada sisi yang lain, pengaruh budaya asing melalu penyebaran teknologi inforamasi di berbagi platform digital seperti facebook, yutube wastApp, tiktor, twiter dalan telah menjadi gaya dan pola hidup baru bagi geresi muda. Bahkan generasi tua pun juga ikut terpengaruh dengan arus perkembangan teknologi informasi. Sehingga sering kita jumpai dalam keseharian beberapa orang tua lebih senang bermain facebook, WastApp, maupun nonton yutube sebagai kebiasaan baru dari pada belajar dan mengajarakn anakanak mereka untuk membaca Al-Qur'an atau ilmu agama lainnya. Pada sisi inilah adanya hal kontras dalam kehidupan masyarakat, yakni ada sebagian anak-ana remaja, pemuda, termasuk orang dewasa orang minatnya kurang utuk belajar Al-Qur'an seperti Tahsin atau membetulkan bacaa'an Qur'an, maupun bacaan Shalat. Padahal belajar ilmu agama merupakan suatu kewajiban dan keharusan bagi seorang orang beriman dimana ia berada. Belajar ilmu agama akan menjadi penereang hidup di dunia dan akhirat nanti. Kondisi inilah yang menjadi dasar, penyelenggaran kegiatan tahsin dan lomba adzan bagi melalui program KKN-PAR IAI Muhammadiyah Bima di Kelurahan Oi Fo'o Kota Bima.
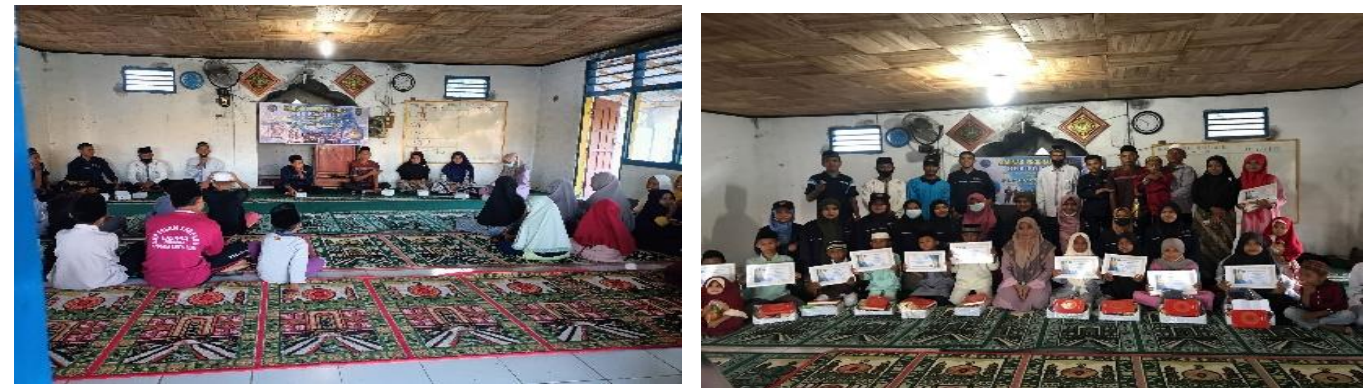

Gambar 3. Kegiatan Pemninaa Tahsin Dan Laom Adzan Di Kelurahan Oi Fo'o Kota Bima

Kegiatan dilaksanakan pada hari Minggu, 22 Agustus 2021 di Masjid Ar-Rahman lingkungan Rade Ndeu. Promosinya dengan cara membuat brosur pendaftaran lomba. Cara pendaftarannya berupa pengumuman di masjid, pembagian brosur di sekolah yang ada di Kelurahan Oi Fo'o Kota Bima dan di tiap-tiap TPQ. Tujuannya agar memotivasi anak-anak dalam membaca dan menghafal Al-Qur'an serta mampu melafalkan adzan secara secara sempurna. Peserta lomba ini diantaranya ada anak-anak di tingkat SD dan SMP. Peserta yang daftar lomba ini ada 40 orang. Pemenang dalam lomba ini terdiri dari 14 orang yaitu 4 orang lomba adzan tingkat SD, 4 orang lomba hafalan tingkat SD, 3 orang lomba adzan tingkat SMP, dan 3 orang lomba hafalan tingkat SMP. Dengan kegiatan pembinaan keagamaan semaca ini, diharapkan para remaja, orang tua dan tokoh masyarakat di Kelurahan Oi Fo'o Kota Bima akan lebih peduli dan memiliki minat ynag tinggi untuk beljara ilmu agama terutam dalam memca Qur'an. Sebab posisi Islam akan lebih kokoh bilamana semua generasi Islam senantiasa memposisi Al-Qur'an sebagi sumber pengetahuan, sebagi sumber hukum, sebagai pedoma perilaku dan keadaban diri dalam memanimalisir pengaruh dari gencarnya upaya-upaya sekularissai 
dari berbagai kelompok/organisasi yang pro liberalisme kehidupan masyarakat melalui media teknologi informasi dewasa ini. Oleh karena itu, penting bagi setiap masyarakat agar tetap menggalang sefta menumbuhkan antusias dalam diri untuk mengitu kegiatan keagaman khusunya di Kelurahan Oi Fo'o Kota Bima.

Berdasarkan uraian di atas, bahwasannya pengembangan program penguatan pemahaman bidang sosial dan keagamaan bagi masyarakat melalui kegiatan KKN-PAR di Kelurahan Oi Fo'o Kota Bima, menurut hemat penulis paling tidak ada tiga hal yang dapat dipahami secara bersama antara lain; 1) Penting bagi setiap anggota masyarakat dalam hal ini para remaja, orang tua, tokoh agama, tokoh pendidikan dan para pejabat pemerintahan, untuk senantiasa membangun kesadaran kolektif secara berelanjutan dalam memerangi penggunaan narkoba dala kehidupan sosial masyarakat di Kelurahan Oi Fo'o Kota Bima. Daam kondisi apaupun, orang tua dan tokoh masyaraka harau menjadi garda terdepan dalam mengawasi setaia tindakan para remaja di lingkungan sekitar agar tidak terjebak mengkonsumsi narkoba/narkotika dalam bentuk maupun jenis apapun. Sehingga setiap orang berani untuk mengatakan "no narkoba" sebagai prinsip diri agar menjadi manusi yang lebih baik, lebih sehat, dan memilki visi dalam kehdipuan sosial masyarakat di Kelurahan Oi Fo'o Kota Bima.

2) Penting bagi orang tua, tokoh masyarakat dan pemerintah setempat untuk membangun pemahaman dan kesasadaran bahwa proses pernikahan remaja pada usia dini, memberikan dampak buruk bagi masa depan anak dan keharmonisan keluraga di masa depan. Sebab kondisi emosional dan psikolgis seorang anak pada usia dini, belum sepenuhnya stabil atau belum memiliki pola pikir dewasa sebagaimana mestinya, bila dihadapkan dengan beban tanggung jawab sebagai seorang suami maupun istri dalam kehidupan berumah tangga. Pada akhirnnya akan menjerumuskan seorang anak pada tindakan kekerasan dalam rumah tangga (KDRT) dan berujung pada perceraian, sehingga hal-hal inilah yang mesti diperhatikan oleh masyarakat di Kelurahan Oi Fo'o Kota Bima. 3) Penting bagi orang tua, tokoh agama dan pemerintah setempat dalam menyelenggarakan kegiatan-kegiatan kegamaan secara berkelanjutan sebagai program prioritas, guna memantik minat dan antuisias para remaja agar lebih Islami dalam berprilaku, tanpa terpengaruh oleh gempuran media teknologi dan informasi digital seperti; permainan game online, tiktok dan lain sebagainya. Pada kahirnya akan menjadi generasi Islam yang beradab, yang mencintai Al-Qur'an dan berakhlak nulkarimah pada setiap tindakan daan perbuatan dalam kehidupan sosial masyrakat di Kelurahan Oi Fo'o Kota Bima.

\section{SIMPULAN}

Berdasarkan uraian kegiatan pengabdian masyarakat terkait dengan pentingnya pengauatan pemahaman bidang sosial dan keagamaan bagi masyarakat melalui kegiatan KKN PAR di Kelurahan Oi Fo'o Kota Bima disimpulkan bahwa untuk memanimalir potensi pengguanaan narkoba pada kalangan remaja diperlukan perhatian bersama secara kolektif dan bekelanjutan mulai dari para orang tua, tokoh agama, tokoh masyarakat termasuk unsur pemerintah setempat untuk berperan aktif dalam mensosialisasikan bahaya narkaba/narkotika bagii masa depan seorang anak. Pada persoalan lain seperti adanya pernikah remaja pada usia dini (belum dewasa), secara sosial juga berdampak pada keharmonisan kelurga bagi pasangan yang menikah muda. Sebab, seorang remaja yang dihadapkan dengan tanggung jawab sebagai seorang suami maupun istri sebelum 
sepenuhnya siap dengan segala tanggung jawab yang dipikulnya. Kondisi ini dikarenakan perkembangan tingkat emosional pada usai remaja belum sepenuhnya dewasa. Dalam kondisi inilah pasangan muda, seringkali dihadapkan dengan tindakan kekerasan dalam rumah tangga (KDRT) dan berujung pada perceraian. Dengan demikian adanya kegiatan seminar "pencegahan penggunaan narkoba bagi generasi muda" dan sosialisasi terkaiat "dampak sosial pernikahan usia dini" di Kelurahan Oi Fo'o Kota Bima, secara berkelanjutan akan memberikan dampak positif dalam membangun kesedaran dan pemhaman bagi masyarakat agar tidak melalukan perbuatan-perbuatan melangggar hukum seperti menggunakan narkoba dan melakukan pernikahan pada usia dini bagi remaja di lingkungan Kelurahan Oi Fo'o Kota Bima.

\section{UCAPAN TERIMA KASIH}

Penulis mengucapkan terima kasih kepada Lembaga Penelitian dan Pengabdian Kepada Masyarakat (LP2M) Institut Agama Islam (IAI) Muhammadiyah Bima yang telah memberi dukungan moril dan material melalui kegiatan program KKN-PAR tahun 2021, sehingga kegiatan pengabdian masyarakat dapat diselenggarakan dengan efektif. Pada akhirnnya kegitan pengabdian masyarakat ini juga akan berdampak positif terhadap peningkatan kapasitas pemahaman bidang sosial dan keagamaan bagi masyarakat di Kelurahan Oi Fo'o Kota Bima.

\section{DAFTAR PUSTAKA}

Agus Afandi, dkk. (2015). Modul Participatory Action Research (PAR) untuk Pengorganisasian Masyarakat (Community Organizing). Surabaya: LPPM UIN Sunan Ampel.

Alfa, F. R. (2019). Pernikahan Dini Dan Perceraian Di Indonesia. Jurnal Ilmiah Ahwal Syakhshiyyah (JAS), 1(1), 49. https://doi.org/10.33474/jas.v1i1.2740

Amiruddin. (2021, June 20). Kondisi Pengembangan Bidang Sosial Keagamaan di Kelurahan Oi Fo'o Kota Bima [Personal communication].

Arsip. (2015). Data Pengembangan Infrastruktur Di Kelurahan Oi Fo'o Koat Bima.

Faridatul Jannah, U. S. (2012). Pernikahan Dini Dan Implikasinya Terhadap Kehidupan Keluarga Pada Masyarakat Madura (Perspektif Hukum Dan Gender). Egalita. https://doi.org/10.18860/egalita.v0i0.2113

Mansour, F. (2002). Jalan Lain. Yogyakarta: Pusataka Pelajar.

Moh. Nazir. (2005). Metode Penelitian. Jakarta: Ghalia Indonesia.

Muh. Adnan. (2021, June 27). Kendala Pendidikan Islam Bagi Anak Di Kelurahan Oi Fo'o Kota BIMA [Personal communication].

Purwatiningsih, S. (2016). Penyalahgunaan Narkoba Di Indonesia. Populasi, 12(1). https://doi.org/10.22146/jp.12275

Puslitdatin BNN. (2019). Penggunaan Narkotika di Kalangan Remaja Meningkat. Jakarta: Badan Narkotika Nasional (BNN). https://bnn.go.id/penggunaan-narkotikakalangan-remaja-meningkat.

Suwartiningsih. (2015). Implementasi PAR Dalam Pendidikan Agama Islam. Jurnal Paradigma, 2(1), 3.

Tim KKN PAR. (2021). Hasil Observasi Kegiatan KKN-PAR di Kelurahan Oi Fo'o Kota Bima. Lalpran KKN. 
Tim LPM. (2008). Modul Pelatihan Kuliah Kerja Nyata (KKN) Transformatif IAIN Sunan Ampel Surabaya. Suarabaya: LPM IAIN Sunan Ampel.

Tim LPPM. (2020). Buku Pedoman KKN-PAR LPPM IAI Muhammadiyah Bima. Kota Bima: LPPM IAIM Bima. 